\title{
Interrogating disability and prosthesis through the conceptual framework of NEODISABILITY
}

\author{
By Tine Fristrup \& Christopher Karanja Odgaard
}

\begin{abstract}
This article investigates the emerging field of critical disability studies in order to explore understandings of disability and prosthesis through the intersection of dis/ability studies, studies in ableism, and philosophical enquiries into the biopolitics of disability and neoliberal psychopolitics. We present the interpretation that contemporary Western ableism is configured by neoliberal arrangements operating on the individual in ongoing processes of self-improvement. People who fail in the achievement society see themselves as being responsible for their own situation, blaming themselves as individuals instead of questioning the ableism that organises contemporary societal orderings in the neoliberal production of inferiority. We offer a conceptual framework of neodisability by unfolding internalised disabling processes in which the bifurcation of 'dis' and 'ability' operates through the forward-slash in dis/ability. The forward-slash captivates the optimistic cruelty in the workings of contemporary ableism in search of excellence through prosthetic configurations in an achievement economy: desiring the invisible prosthesis of willpower in the constant pursuit of overcoming the 'dis/'. Neodisability engenders contemporary psycho-neoliberal-ableism, with people turning their aggressions against themselves in never-ending processes of dis-ing parts of themselves as 'notfit-enough', while being in constant need of therapeutic interventions to employ and promote the self-optimising efforts in times of neodisableism.
\end{abstract}

KEYWORDS: Dis/ability, ableism, dis-ing, neoliberalism, biopolitics, psychopolitics.

TINE FRISTRUP, PhD, Associate Professor, Danish School of Education, Aarhus University

CHRISTOPHER KARANJA ODGAARD, BA in Social Education and MA in Educational Sociology, Aarhus University 


\section{A conceptual framework of neodisability}

Critical Disability Studies is a 'location populated by people who advocate building upon the foundational perspectives of disability studies whilst integrating new and transformative agendas associated with postcolonial, queer and feminist theories' (Goodley 2016, 190-191). This merging of epistemological perspectives and ontological desires has created a rich tapestry of concepts and frameworks (Goodley et al. 2019, 974).

In keeping with this rich tapestry of concepts and frameworks, we align the conceptual framework of neodisability with the exponential rate of scholarship productions in critical disability studies according to Dan Goodley et al. (2019). Their concern encompasses how it is possible to hold the dual interest between the established theories of disability and disablism alongside nascent critical studies of ability and ableism, without watering down the politics of disability on which studies of disability were based in the past. They make a new case for reflexive and politicised critical disability studies, and we follow this emphasis with the conceptual framework of neodisability.

According to Dan Goodley, the logic of neoliberal-ableism is a philosophy that pursues "the (hyper) normal" (Goodley 2014, xiv). Hyper normality echoes Fiona Kumari Campbell's understanding of ableism as an epistemology locating "the perfect, species typical and therefore essential and fully human" (Campbell 2001, 44). The entanglement "between epistemologies (knowledge-forms) of ableism and the production of internalised ableism" (Campbell 2009, 23), as Campbell argues "induce an internalisation or self-loathing" (Campbell 2009, 20). In his book titled Psychopolitics (2017) Byung-Chul Han defines our contemporary ableism as a form of neoliberal psychopolitics which is dominated by the excess of positivity and works with positive stimuli "as a machine of positivity and with the compulsion always to achieve more and more" (Han 2017,
32). The imperative of neoliberal-ableism in a psychopolitical framing is the workings of boundless optimisation leading to mental collapse because "the ego grapples with itself as an enemy" (Han 2017,30 ). Our understanding (as well as critique) of neoliberal-ableism in a psychopolitical framing coincides with Hi'ilei Julia Kawehipuaakahaopulani Hobart and Tamara Kneese's formulations of neoliberal self-care, as "[b]oth a solution to and a symptom of the social deficits of late capitalism, evident, for example, in the way that remedies for hyperproductivity and the inevitable burnout that follows are commoditized in the form of specialized diets, therapies..." (Hobart \& Kneese 2020, 2). When unpacking compulsory ableist notions, we begin to address what Han calls "the course of inaugurating the age of exhaustion" (Han 2017, 30). Contemporary ableism operates in the realm of the burnout society (Han 2010); where neuronal power functions in favour of hybridisation beyond borders, transitions, thresholds, fences, ditches, and walls in order to accelerate universal change and exchange. The excess of positivity concerns the surplus positivity and the violence of positivity "that derives from overproduction, overachievement, and overcommunication" (Han 2010, 5). According to Han, "the violence of positivity does not deprive, it saturates; it does not exclude, it exhausts" (Han 2010, 7); and depression, ADHD and burnout syndrome are all indicators of an excess of positivity. Mental maladies such as depression and burnout "express profound crisis of freedom as they represent pathological signs that freedom is now switching into manifold forms of compulsion" (Han 2017, 2). When building from Han's approach to psychopolitics, we disclose an achievement economy that is working beyond overcoming physical resistance and in the direction of optimising physical processes. In this setting, we take Sharon L. Snyder and David T. Mitchell's understanding of the biopolitics of disability within contemporary neoliberal biopolitics that "references all bodies as deficient and in need of product supplementations to treat the in-built inferiority within, a system of bodily referencing shorn of environmental causes" (Mitchell and Snyder 2015, 39-40) in the direction of the psychopolitics of ability. 
In the conceptual framework of neodisability, the psychologicalisation of ableism does not emphasise the Cartesian split between body and mind because contemporary ableism can be elaborated as a way of making governable bodies through psycho-power which (as Han points out) follows the political rationality of bio-power (Han 2017). Our conceptualisation of neodisabilty does not subscribe to any clear-cut distinction between able-mindedness and/or able-bodiedness when scrutinising ableism. When we elaborate contemporary ableism through the prism of neoliberal psychopolitics, we are standing on the shoulders of different disciplines embracing body politics as a crucial point of reference, following the feminist thinking of Donna J. Haraway. Haraway points to the union of the political and the physiological by underlining that "bodies, then, are not born; they are made" (Haraway 1991, 208). When applying the non-essentialist body politics of Haraway to the framework of neodisability, bodies are made through contemporary ableism and the knowledge available to produce govern-able subjects that live by the affective formation of cruel optimism (Berlant 2011) embedded in the union of the political, the physiological and the psychological. When analysing ties between affect studies and critical disability studies, Dan Goodley, Kirsty Liddiard and Katherine Runswick-Cole (2018) describe the ramifications of Lauren Berlant's notion of cruel optimism as producing "feelings of emotional and ontological invalidation" (208) with the risk of "causing emotional distress, as one fails to match up to the labour and consumption demands of late capitalism" (209).

With cruel optimism enveloped in the achievement economy, practices of prosthetic solutions alter distinctly, as the notions of failure are embedded in the achievement economy, shifting "the prostheses' function from supplementation to enhancement", according to Hsiao-yu Sun $(2018,15)$. This entails that rehabilitating efforts relying on prosthetic solutions likewise shift their emphasis: from substitution in order to overcome disablement/disability to optimisation in order to retain abledment/ability. In a medical approach to disability, prosthesis signifies the absences or deficiencies of the disabled body, thereby functioning as a substitution by adding or supplementing normalcy and wholeness to the abnormal and inadequate body. When we operate in an achievement economy, the rehabilitating efforts of self-optimising processes work through an understanding that prosthesis is "the invisible prosthesis of willpower" (23) in search of perfectability. This exploration of prosthetics counters the emergence of the normal body as neodisability by accentuating the current promotion of the hypernormal body through a kind of nonmaterial prosthetic embedded in never-ending therapeutic interventions that maintain the psycho-neoliberal-ableist prerogative.

\section{A case of neodisability in higher education}

To demonstrate how the conceptual framework of neodisability works, we present an outline of a statement written by a Danish student named Naja Momberg Christiansen, published in the Danish newspaper "Dagbladet Information" on 22 June 2019:

The market has made me mentally ill. It is nourished by the fact that we feel bad about ourselves. Although I think I can see through the neoliberal market logic prevailing throughout society, I am unable to escape from it. It has installed a sense of inferiority in me which has triggered an eating disorder. [ ] Unfortunately, I cannot find any answers to this problem. However, I realise that the neoliberal, economic mindset has become the answer to the serfdom of ancient times, but places Man in the very chains from which it once freed us. [] You cannot be present without constantly being confronted with your inferiority - more or less unspoken: You are not good enough. You cannot cope with the labour market today without focusing on how to be more efficient and productive by moderating and improving your efforts (Christiansen 2019 - translated by the authors). 
This student claims that the neoliberal configuration of contemporary society has triggered her eating disorder. At Aarhus University in the spring semester of 2016, it was discovered that the number of students availing themselves of the special educational support service owing to psychological or neurological diagnoses had increased by 27 per cent over a two-and-a-half-year period (Omnibus 2016). This radical increase in the number of students seeking this kind of help in the year 2016 aligns with the study progress reform in Danish higher education in 2014, a reform which aimed to reduce the average length of time students took to complete their university education. There were changes in Danish higher education in the wake of neoliberal reforms of austerity, with modalities of time, speed and support entangling and creating new forms of precarity embedded in the production of deficiency and inferiority, and causing a radical increase in psychological and neurological disorders among students at Aarhus University from 2014 to 2016. The university's special educational support service has become a personalised prosthetic solution to an inherently political problem. When the number of psychological and neurological disorders increases in society and higher education, it engenders psychopolitical prosthetic solutions such as support systems based on forms of therapeutic interventions. At Aarhus University, the Support Centre has become a self-contained unit inside the university with its own finances. In 2012 it had a budget of DKK 33 million (Aastrup 2011), which was two years before the implementation of the study progress reform in 2014 pointing to the 27 per cent increase in psychological and neurological diagnoses. Whether the budget has increased with the same percentage can only lead to speculation in how the enterprise has grown. The therapeutic (and in this case pedagogical) efforts in the support system have led to what the Danish economist Mogens Ove Madsen (2009) has called an "entrepreneurial university" embedded in a globalised knowledge economy, acting on the premise of the market in creating new enterprises as a consequence of the university reform in 2003. Such a marketisation of higher education has developed a support system that seems to function as a prosthetic arrangement for students with diagnoses.

Until 2012, the special educational support offered to students with a diagnosis by the Support Centre at Aarhus University was framed by educational psychology based on Lev Vygotsky's cultural-historical theory combined with philosophical enquiries into existentialism and psychoanalysis (Dræby Sørensen 2016). This combination is no longer applied in the Support Centre's pedagogical interventions, which are now based on the perspective of Vygotsky alone (Pedersen and Pors Knudsen 2015). The support works as a prosthetic pedagogy through Vygotsky's concepts of scaffolding and zone of proximal development, enabling students with a diagnosis to learn what they do not yet know through the guidance of teachers or advanced peers in processes of mentoring. Mentoring reframes the individual problems embedded in medical diagnoses by emphasising structural problems in order to overcome the diagnostic deficit approach (Pedersen and Pors Knudsen 2015). The educational support system works through the deficit model legitimised as a way to compensate the physical, psychological and neurological deficits or impairments operating on the logic of disorders as pathological a thus as an anti-thesis to normalcy and therefore in need of a pros-thesis in order to rehabilitate the equilibrium from before the deficit through prosthetic solutions. At the Support Centre, they try to resist the synthetic closure in the dialogical framework of thesis/antithesis/synthesis through a prosthetic pedagogy embedded in scaffolding as a prosthesis that will act as an enabler and not a disabler. In this regard, the prosthetic arrangements in the Support Centre employ knowledge of critical psychology aiming towards sustainability in order to prevent students from developing mentoring dependencies. This effort, focusing on the sustainability of the student's subjectivity, underlines the pedagogical approach to prosthesis in contrast to the therapeutically orchestrated configuration of prosthesis, the latter enclosed in the will to dependency as part and parcel of the support systems, i.e. the prosthetic solutions, engendering the imperative of growth and perfectability within 
neoliberal economics and contemporary ableism. Contemporary ableism embraces prosthesis as the representation of excess pointing to the excess of positivity rooted in the neoliberal marketisation and the economic ordering of society. Vygotsky's scaffolding and zone of proximal development affirm a learning distance between the present and the future where the former, within the 'entrepreneurial university', translates into diminished and the latter into augmented in accordance with neoliberal marketisation and the production of 'surplus'. The overcoming of this distance is the continuous aiming at excessing positivity as the never-ending pursuit to get a step closer to the value of surplus.

Unfortunately, this exhausting effort, as intrinsic it might be to contemporary ableism, evokes cruelty in its practice, because one will never succeed in reaching excess. No matter how much energy is put into the effort, one will continue to fail as the goalpost of ableism continues to be out of reach. This is the ongoing process of internalised disabling, or as we would like to present it here in the conceptual framework of neodisability: an ongoing process of (bodily) dis-ing. As Goodley and Runswick-Cole (2016) argue, to dis is to trouble. Following this understanding, we separate dis and ability into a bifurcation rubbing against the forward-slash on both sides demonstrating how the forward-slash incarnates the prosthetic arrangements in excessing positivity. We simply place excess on the right side of the forward-slash, thus illustrating the connection between excess and ability, showing how the 'dis/' continuously tries to overcome the forward-slash as if it was a barrier in order to approach excess illustrated through "/ability' or '/ableism'. The 'dis/' displays deficiency and inferiority with a relational reference to perfection and superiority as '/ableism'. This process emerges clearly in the case of the Danish student Naja Momberg Christiansen and her experience of inferiority propelling an eating disorder because of the constant pressure to overcome 'dis/' and move towards '/ableism' as being preyed upon by the compulsory excess of positivity. This process of dis-ing highlights the disjunctive, incongruous and fragmented bodily terrains in search of excellence, desiring excess of positivity. In these desiring efforts, the dis becomes a formation of 'dis/ability' and lacks the possibility of troubling '/ability'. It is the desiring efforts that engender inferiority as people turn their aggression against themselves in a constant process of dis-ing parts of themselves as not-yet-fit (not necessary degenerated) but in constant need of therapeutic interventions or quick fixes. Neodisability becomes a way to conceptualise the interdependency between 'dis' and 'ability' through the forward-slash in dis/ability, which underlines our point of departure in critical dis/ability studies.

\section{Departing from critical dis/ability studies and studies in ableism (SiA)}

"Disability is always haunted by the spectre of ability", Goodley writes in the closing chapter of his book, thus summarising his overarching theoretical project as "working the dis/ability complex" (Goodley 2014, 153). Throughout the book, Goodley polemically explores the binary imaginaries dividing the dichotomised notions of disability and ability by contesting the static binary divide itself (this is indicated by a forward slash in between 'dis' and 'ability': dis/ability). Instead, Goodley argues, we have to begin to "think simultaneously about disability and ability" (Goodley 2014, xi). As a theoretical project, Goodley's conceptualisation of dis/ability departs from what he describes as British disability studies and the steadfast fixation within the social model of disability, yet without disavowing the importance of the social model acknowledging "that the social model of disability has saved and continues to save lives" (Goodley $2014,7)$. What essentially separates Goodley's project of dis/ability studies from the social model of disability is on the one hand, the project's tandem understanding of disablism and ableism as complex, unstable and continuously overlapping vectors, and on the other hand, the project's intersectional and transdisciplinary subscriptions aligning dis/ability studies with "political and thinking allies - others who are engaged in contesting oppressive practices" (Goodley 2014, xiv). More specifically, dis/ability studies find this intersectional 
alignment among other "non-normative, queer, crip and marginalised Others and their allies" (Goodley $2014, x$ ). Dis/ability studies are founded on a substantial subscription to work 'outside' the field of disability studies, in particular queer, postcolonial and feminist thinking.

Following Goodley's approach to dis/ability, we understand the dividing practices between disablement and ablement as constructions of disablism in the wake of contemporary ableism. Our understandings of ableism are elaborated with reference to Fiona Kumari Campbell's work (2001, 2008a, 2008b, 2009, 2012, 2017, 2018, 2019), in particular her latest attempt to develop studies in ableism (SiA) as a research methodology. When accentuating ableism, we cease from confining our enquiry into disablism and its practices and production, while losing sight of the constitutive other of disablism: ableism. Studies in ableism explicitly insist upon the exploration of epistemologies and ontologies that constitute contemporary ableism as "a network of beliefs, processes and practices that produces a particular kind of self and body (the corporeal standard)" (Campbell 2001, 44).

Recognising the subtle nature of ableism which makes it (according to Campbell) "hard to pin systems of ableism down because these systems are a series of permeable practices" (Campbell $2019,11)$, we draw on Campbell's presuppositional construction of the "foundations of systems of ableism" (Campbell 2019, 1), in order to grasp the densely complex and slippery notions of ableism. In her 2019 article "Precision ableism: a studies in ableism approach to developing histories of disability and abledment", Campbell puts forward both a definition of ableism and a methodological approach aimed at researching ableist formations. It is crucial, at this juncture, to note that Campbell's thinking on ableism draws strongly on the work of Foucault and his original formulations on subjectivity and power concerning dividing practices 'between' and 'within' (Foucault 1982a). This is most evident when Campbell refers to ableism as both dividing elements and dividing practices (Campbell $2019,11)$. In this way, ableism always consists of relations 'between' and 'within' as relations of ableism or ableist relations (Campbell 2019, 15), which constitute the (prosthetic) formation of 'dis' concerning ableism/ability as dis/ableism or dis/ ability. In this setting, the forward-slash indicates the relational aspect and points to "an ontology of negation or absence but still situated within an ontological paradigm" (Campbell 2019, 11). Campbell further refers to ableism as something which is practised in the West in relation to demands for "an unbridled form of individualism that is pre-occupied with continuous self-improvement and corporeal enhancement (fit, benchmarked and upgradeable bodies) that struggles with the reality of illness, disability and contingency" (Campbell 2019, 11).

Campbell continues her outline of the dividing elements with a particular emphasis on the ableist relations concerning the notion of the normative and what she called "a constitutional divide" (Campbell 2009, 6). In 2019, Campbell elaborated this divide as a system with two elements, "namely the notion of the normative (and normal individual, e.g. the prized body/mind/aesthetic) and the enforcement of a divide between a so-called perfected or developed humanity (how humans are supposedly meant to be) and the aberrant, the unthinkable, underdeveloped and therefore not really human" (Campbell 2019, 11). Preoccupied with the order(ing) of sentinent life, the ableist divide splinters life into demarcated and fixed bodily states of being, which in turn strengthen a fantasy of corporality, "where the uncertainties and leakiness of the body dis-appear within a teleological narrative of 'progress', improvement and empire building towards a pristine model of ablement" (Campbell 2019, 11). Campbell argues that "with the development of enhancement technologies (cosmetic neurology and surgery for instance) the notion of the norm is constantly sliding, maybe creating a larger pool of 'abnormal' persons who because of 'choice' or limited resources cannot 'improve' themselves and hence lapse into deficiency" (Campbell 2019, 12). It becomes clear that any enquiry into an ableist belief system surely requires some form of articulation on the underpinnings of such a system. This begs the question: what undergirds contemporary ableism? What 
compounds - in terms of structures and trajectories (economically, ideologically and culturally) such an ableist belief system?

Searching for answers to these questions requires, as Goodley writes, an "unpacking [of] the ableist context" (Goodley 2014, 26) in demonstrating that "ableism clings to economic and ideological conditions" (Goodley 2014, 26), which reveal ableism in its current adherence to neoliberalism. This ongoing affiliation, ableism vis-á-vis neoliberalism leads Goodley to define our current ableism as "neoliberal-ableism" (Goodley 2014, 26). We correspond with Goodley's understanding of neoliberalism as "providing the ecosystem for the nourishment of ableism" (Goodley, Lawthom and Runswick-Cole 2014, 981). It is crucial to underscore that any robust attempt to analyse the contemporary formations of ableism involves scrutinising the rise of neoliberalism and neoliberal subject formations. However, accepting this entanglement between the two (neoliberalism and ableism), as Campbell cautions us, does not liberate us from taking into account the fact that "[a] bleism is everywhere, but its manifestations as a practice are not the same everywhere and in every moment" (Campbell 2019, 17). Hence, the examination of ableist formations entails uncovering distinct circumstances that give rise to particular historically situated ableist formations. When examining contemporary ableism in relation to neoliberal-ableism, we frame ableism in accordance with Foucault's genealogy of advanced liberal government, as the birth of biopolitics in the eighteenth century, when "the administration of bodies and the calculated management of life" (Foucault $1978,140)$ underlined the disciplinary approach to the ordering of society and the abbreviation of power over life as the performances of the body became an investment in life itself, in contrast to the sovereign power as a power of death. Within the era of biopolitics, the population became the centre of political attention and "an indispensable element in the development of capitalism" (Foucault 1978, 141), with its standard reference to growth concerning both the phenomena of population and the economic processes in favour of availability and docility.
According to Foucault, the biopolitical had to opt for "methods of power capable of optimizing forces, aptitudes, and life in general without at the same time making them more difficult to govern" (Foucault 1978, 141). Biopower disciplines the social body through institutions like the family, the army, schools and the police, individual medicine and the administration of collective bodies (Foucault 1978, 141) within the realm of segregation and social hierarchisation in order to valorise investments in bodies as the celebration of human growth and an expansion of productive forces. Disciplinary power makes it possible to control life by managing risks (of death) and adjusting individual behaviour to improve collective welfare. Biopolitics is at the forefront of disciplining the bodies in the regulation and optimisation of the population.

\section{The biopolitics of disability}

Neoliberalism, as Mitchell and Snyder argue, thrives on the production of new spaces for exploitation. Today, the body has become a multisectional market, with neoliberalism dividing us within our bodies as we become "perpetual members of an audience encouraged to experience our bodies in pieces - as fractured terrains where the 'bad' parts of ourselves are ever multiplying" (Mitchell and Snyder 2015, 221).

In following Mitchell and Snyder, we access the scenes of division within our bodies under the biopolitics of late capitalism, which trains everyone to separate the 'good' and the 'bad' parts. This kind of internalised disabling is based in inferiority: always failing to become 'good enough'. This neoliberal logic incarcerates what Berlant has described as cruel optimism:

[] a relation of attachment to compromised conditions of possibility whose realization is discovered either to be impossible, sheer fantasy, or too possible, and toxic. What's cruel about these attachments, and not merely inconvenient or tragic, is that the subjects who have $x$ in their lives might not well 
endure the loss of their object/scene of desire, even though its presence threatens their well-being, because whatever the content of the attachment is, the continuity of its form provides something of the continuity of the subject's sense of what it means to keep on living on and to look forward to being in the world (Berlant 2011, 24).

Building from Berlant, one could summarise that even though you work hard on the betterment of your body in your desire to improve your achievements, you will never feel fulfilled; you can always work a little bit more or want more - in order to improve more. This cruel optimism points to the cruelty in desiring practices because desiring means always wanting more and never being fully satisfied; continuously striving for perfectibility, which in turn can never be accomplished or fulfilled due to the logic of the market operating on individual practices of self-enhancement. Following Berlant, the object of desire "contributes to the attrition of the very thriving that is supposed to be made possible in the work of the attachment in the first place" (Berlant 2006, 21). This indicates that the subject is optimistically attached to an object of desire despite the disappointments, leading to "a cluster of promises we want someone or something to make us and to make possible for us" (Runswick-Cole and Goodley 2015, 167). This resonates with Foucauldian understandings of the biopolitical constitution of desire and the emerging individualised responsibilisation in which, as argued by Runswick-Cole and Goodley: "The individual is asked to solve their problems that, at the bottom, are not individual problems to solve" (Runswick-Cole and Goodley 2015, 168).

The neoliberal agenda works with and against your desires while marketisation is staging a cruel optimism that comes into play as a never-ending capacitation of what rightly could be seen as incapacitation. According to Mitchell and Snyder, incapacity becomes a capacity in the neoliberal marketplace, and "the late capitalist litany of bodily frailties, imperfections, and incapacities gluts advertising networks as the hegemonic product pitch strategy of today" (Mitchell and Snyder 2015,
220). Within such treatment-based environments, "disability rapidly becomes synonymous with a humanity that we are all seeking to overcome" (Mitchell and Snyder 2015, 220). When imperfections and incapacities become the reference for marketisation, "new industries of comfort" (Mitchell and Snyder 2015, 220) transcend disciplinary regimes of the therapies and their medically subordinate position within the health sciences to become our mainstream training gurus for improving on bodily imperfections writ large. When capacitation in neoliberal-ableism becomes a question of targeting our efforts to overcome a constant incapacitation or debilitation of our bodies through internalised dividing practices, the notion of disability can be explored and (re)conceptualised as neodisability.

Thus, neodisability is embedded in neoliberal-ableism and the ceaseless pursuit of rehabilitation to improve the not necessarily degenerated or lost parts of the body, but rather the parts that can be improved and become even better than before the therapeutic intervention. In other words, this is a never-ending story: an infinite movement in an achievement economy, where bodily parts are constantly scrutinised within the neoliberal demands and standards of productivity.

Neodisability, we argue, explores disability by pushing disability beyond its negatively determined disabled subject and into a positive determination of the ableist achievement subject. In the exploration of disability, neodisability is embedded in the economic discourse concerning what Yann Moulier Boutang (2008) has described as cognitive capitalism, where immaterial labour works in contrast to Karl Marx's category of abstract labour. In this way, the conceptual framework of neodisability points towards an understanding of ableism which is enrolled in the efforts of the economics of cognitive capitalism. The exploration and rearticulation of disability is somewhat different from the articulation of the division between impairment and disability in terms of the social model of disability. The social model refers to a sociological turn in disability studies, whereas the framing of neodisability aligns with the turn towards studies in ableism ( $\mathrm{SiA}$ ) and an intersection with philosophical and cultural studies on 
societal transformations as an analytical prism. The emphasis on neo in neodisability refers to both neoliberal-ableism and the production of new forms of disability engendered in the precarious self-exhaustion as the psychological efforts become the productive force in Western societies.

\section{Neoliberal psychopolitics}

Following the previous part of the article, we outline systems of ableism as a system of dividing practices, thus understanding dividing practices as being aligned with Foucault's central formulation of biopolitics and his turn towards technologies of the self in the early 1980s. Foucault developed the historically situated ethics of the self. And according to Han, Foucault did this in a context which was primarily detached from technologies and techniques of power and domination: "Consequent$l y$, it is often assumed that his [Foucault's] ethics of the self stands in opposition to power and domination. Indeed, Foucault himself pointed out the shift he was making from technologies of power to technologies of the self" (Han 2017, 27). Han points out that Foucault's analysis of the technology of power under the neoliberal regime overlooked the fact that the neoliberal regime claims the technology of the self completely for its own purposes. "Perpetual self-optimization" (Han 2017, 28) becomes the exemplary neoliberal technology of the self that represents a highly efficient mode of domination and exploitation. In his essay "Psychopolitics - Neoliberalism and New Technologies of Power" from 2017, Han outlined how we live in a neoliberal regime governed by psychopolitics that follows from the biopolitical regime outlined by Foucault, in his work on biopolitics. Han unfolds Foucault's analysis of the transitions from the power of sovereignty to the disciplinary power that followed the changes in forms of production by emphasising "the shift from agrarian to industrial production" (Han 2017, 19), and "as industrialization proceeded, it became necessary to discipline the body and fit it to machinic production. Instead of torturing the body, disciplinary power yokes it into a system of norms. [...] The body is calibrated to be a production-unit" (Han 2017, 19-20). Disciplinary power is normative because it subjects the body to a set of rules, norms, commandments and prohibitions to eliminate deviations and anomalies. Han (2017) points to the pursuit of allo-exploitation in both sovereign and disciplinary power constellations. In contrast, psychopolitics unfolds auto-exploitation as "the self-as-a-work-ofart amounts to a beautiful but deceptive illusion that the neoliberal regime maintains to exhaust its resources entirely" (Han 2017, 28). As Han points out, neoliberal psychopolitics is always coming up with more refined forms of exploitation, where "neoliberalism has discovered integral human being as the object of exploitation" (Han 2017, 29). According to Han, the neoliberal regime is in the course of inaugurating the age of exhaustion and the psyche itself. The psychic turn is the turn towards psychopolitics, which connects to the modes of operation of contemporary and cognitive capitalism, as immaterial and non-physical forms of production are what determine today's course of capitalism, where "the body no longer represents a central force of production, as it formerly did in biopolitical, disciplinary society. Now, productivity is not to be enhanced by overcoming physical resistance so much as by optimizing psychic or mental processes" (Han 2017, 25). In following Foucault's biopolitics, we point to the docile body as being compliant to the productive forces through dynamics of inhibition and repression. Still, in following Han's psychopolitics, neoliberal dynamics seeks to activate, motivate and optimise, proving its effectiveness by pleasing and fulfilling instead of operating by the biopolitical means of forbidding and depriving. Psychopolitics help to make people dependent (Han 2017, 14), and neoliberalism has discovered that the psyche is the productive force (Han 2017, 25). In these efforts, psychopolitics has replaced the biological, the somatic and the corporeal as the politics of the body in favour of the politics of the psyche. Han distinguishes between the physical and the mental in stating that "the disciplinary power reaches beyond the physical realm, into the mental sphere" (Han 2017, 20). Disciplinary power operates in biopolitics with its discovery that the population is 
a productive and reproductive mass which should be administered carefully. In contrast, psychopolitics operates on the individual or the person and its internalised divided representation of the self as "a process that objectivizes him" (Foucault 1982a, 208). This objectivisation and fragmentation of the self is a trademark of late capitalism, and corresponds with what Brian Massumi describes as the absorbent way in which "[c]apitalism has learned to descend to the infra-level where the individual is emergently divided among potential inflections of its own self-formative movement" (Massumi $2017,14)$, thus functioning as "[a]n extraction of surplus-value from an infra-level" (13).

When we apply notions of ableism which were initially developed in a more or less articulated biopolitical framework, we opt for a psychopolitical (re)framing of neoliberal-ableism and the outline of the neoliberal achievement subject that engages in auto-exploitation under the neoliberal imperative of self-optimisation. This self-optimisation serves to promote perfect functioning, pointing towards weaknesses and mistakes which need to be dealt with therapeutically to enhance efficiency and performance. In this case, neodisability points towards a necessary questioning of what it means to be human in neoliberal times. Since 2013, Dan Goodley has been working with several colleagues at the University of Sheffield in the UK to pull together an interdisciplinary research centre (iHuman) studying new ways of understanding humanism in the interconnections of culture, economy, human movement and technology (Goodley
2020). Neodisablity offers a perspective on these new understandings of humanism in the contemporary cultural, economic and global context described as posthuman following the work of Rosi Braidotti $(2006,2013,2018)$, and the work of Dan Goodley, Rebecca Lawthom, Kirsty Liddiard and Katherine Runswick-Cole on their intellectual and political project named DisHuman (Goodley 2020). In this project, they embrace "the ambivalence that Braidotti, Wynter, Fanon, and Haraway have towards the human (not least in terms of the dominant ways in which this category has been shaped and morphed in modernity)" (Goodley 2020, 44). The DisHuman project is oriented towards a time when dis/human becomes dishuman, and when thinking about the human involves thinking about disability (Goodley and Runswick Cole 2016). Neodisability encompasses the ongoing workings on being included in the normative order, i.e. ableist order of things. That is why we have to dis the processes of dis-ing in neodisability as a critical intervention into the unsettling of humanism's universalism and the primacy of rationality and the unitary subject (Braidotti 2013).

Neodisability works on the confinement of dis/ability, and we opt for future work on dis/neodisability that emboldens the other side of the binary and troubles neodisability. The question of the human has always been central to the politics of disability, and will continue to be central to the conceptual framework of neodisability, pointing towards DisHuman times and efforts in society in general and in higher education in particular.

\section{References}

Berlant, L. 2011. Cruel Optimism. London: Duke University Press.

Boutang, Y.M. 2008. Cognitive Capitalism. English edition 2011. Cambridge: Polity Press.

Braidotti, R. 2006. Posthuman, All Too Human: Towards a New Process Ontology. Theory Culture Society 23

(7-8), 197-208. DOI: 10.1177/0263276406069232.

Braidotti, R. 2013. The Posthuman. London: Polity Press.

Braidotti, R. 2018. Posthuman Critical Theory. In: Braidotti, R. and Hlavajova, M. eds. Posthuman Glossary, 339-42. London: Bloomsbury.

Campbell, F.A.K. 2001. Inciting Legal Fictions. 'Disability's' Date with Ontology and the Ableist Body of the Law. Griffith Law Review, 10(1), 42-62. 
Campbell, F.K. 2008a. Exploring internalized ableism using critical race theory. Disability \& Society, 23(2), 151-162, DOI: 10.1080/09687590701841190

Campbell, F.K. 2008b. Refusing Able(ness): A Preliminary Conversation about Ableism. M/C Journal, 11(3). Online: http://journal.media-culture.org.au/index.php/mcjournal/article/view/46

Campbell, F.K. 2009. Contours of Ableism. The Production of Disability and Abledness. Hampshire: Palgrave Macmillan.

Campbell, F.K. 2012. Stalking Ableism: Using Disability to Expose 'Abled' Narcissism. In: Goodley, D., Hughes, B. and Davis, L. eds. Disability and Social Theory. New Developments and Directions. Hampshire: Palgrave Macmillan. Chapter 13: 212-230.

Campbell, F.K. 2017. Queer Anti-sociality and Disability Unbecoming: An Ableist Relations Project? In: Sircar, O. and Jain, D. eds. New Intimacies, Old Desires. Law, Culture and Queer Politics in Neoliberal Times. New Delhi: Zubaan Publishers. Chapter 10: 280-316.

Campbell, F.K. 2018. Refocusing and the Paradigm Shift: From Disability to Studies in Ableism. In: Ghai, A. ed. Disability in South Asia. Knowledge and Experience. New Delhi: Sage Publishing. Chapter 3: 38-57.

Campbell, F.K. 2019. Precision ableism: a studies in ableism approach to developing histories of disability and abledment. Rethinking History. DOI: 10.1080/13642529.2019.1607475

Christiansen, N.M. 2019. Article available in the following link: https://www.information.dk/debat/2019/06/ markedet-gjort-psykisk-syg-lever-mennesker-daarligt?lst_tag (05072019)

Dræby Sørensen, A. 2016. Pædagogisk Psykologisk Uddannelsesrådgivning 2004-2011. Aarhus: The State and University Library - Aarhus. 141 pp. Report from The Danish School of Education (DPU - Danmarks institut for Pædagogik og Uddannelse), Aarhus University. Link: https://ebooks.au.dk/index.php/aul/ catalog/book/115 (16082019)

Foucault, M. 1978. The Will to Knowledge. The History of Sexuality. Volume 1. Reprinted in Penguin Books under the present title 1998. London: Penguin Books.

Foucault. M. 1982a. The Subject and Power. In: Dreyfus, H.L. and Rabinow, P. eds. Michel Foucault. Beyond Structuralism and Hermeneutics. Second Edition. 1983. Chicago: The University of Chicago. Afterword: 208-226.

Foucault, M. 1982b. Lectures on Technologies of the self at the University of Vermont, autumn 1982. In: Martin, L. H.; Gutman, H. and Hutton, P. H. eds. Technologies of the self: a seminar with Michel Foucault. 1988. London: Tavistock.

Goodley, D. 2014. Dis/ability studies: Theorising disablism and ableism. London: Routledge.

Goodley, D. 2020. Theorising Disability and Humanity. In: L. Ware ed. Critical Readings in Interdisciplinary Disability Studies (Dis)Assemblages. Critical Studies of Education 12, Cham: Springer. DOI: 10.1007/9783-030-35309-4_4, 41-52. Chapter 4: 41-52.

Goodley, D. \& Runswick-Cole, K. 2016. Becoming dishuman: thinking about the human through dis/ability. Discourse: Studies in the Cultural Politics of Education, 37:1, 1-15, DOI: 10.1080/01596306.2014.930021

Goodley, D.; Lawthom, R. \& Runswick-Cole, K. 2014. Dis/ability and austerity: beyond work and slow death. Disability \& Society. 29:6, 980-984, DOI:10.1080/09687599.2014.920125

Goodley, D., Lawthom, R., Liddiard, K. \& Runswick-Cole, K. 2018. Feeling disability: theories of affect and critical disability studies, Disability \& Society, 33:2, 197-217, DOI: 10.1080/09687599.2017.1402752

Goodley, D., Lawthom, R., Liddiard, K. \& Runswick-Cole, K. 2019. Provocations for Critical Disability Studies. Disability \& Society, 34:6, 972-997, DOI: 10.1080/09687599.2019.1566889.

Goodley, D., Lawthom, R., Liddiard, K. \& Runswick-Cole, K. 2020. The Desire for New Humanisms. Journal of Disability Studies in Education 1. 1-20.

Han, B-C. 2010. The Burnout Society. English edition 2015. Stanford: Stanford University Press.

Han, B-C. 2012. The Transparency Society. English edition 2015. Stanford: Stanford University Press.

Han, B-C. 2017. Psychopolitics. London: Verso. 
Haraway, D.J. 1991. Simians, Cyborgs, and Women. The Reinvention of Nature. London: Free Association Books.

Hobart, H.J.K \& Kneese, T. 2020. Radical Care: Survival Strategies for Uncertain Times. In: Social Text (2020) 38 (1 (142)), 1-16. DOI: 10.1215/01642472-7971067

Madsen, M.O. 2009. Universitets $d ø d$. Kritik af den nyliberale tendens. København: Frydenlund.

Massumi, B. 2017. The Principle of Unrest. Activist Philosophy in the Expanded Field. Link: http://openhumanitiespress.org/books/download/Massumi_2017_The-Principle-of-Unrest.pdf (05102020)

Mitchell, D.T. \& Snyder, S.L. 2015. The Biopolitics of Disability. Neoliberalism, Ablenationalism, and Peripheral Embodiment. Michigan: University of Michigan Press.

Omnibus, 2016. Article available in the following link: http://omnibus.au.dk/en/archive/show/artikel/ flere-studerende-soeger-stoette-paa-grund-af-psykiske-lidelser/ (05072019)

Pedersen, L.M \& Pors Knudsen, M. 2015. Er det mig, der er problemet? - En virksomhedsteoretisk analyse of studiemæssige vanskeligheder. Psyke \& Logos. 36, 67-90.

Runswick-Cole, K. \& Goodley, D. 2015. Disability, austerity and cruel optimism. Canadian Journal of Disability Studies. 4(2), 162-186.

Sun, H-y. 2018. Prosthetic Configurations and Imagination: Dis/ability, Body, and Technology. Literary and Cultural Studies. 44 (1), 13-39.

Aastrup, V. 2011. A power-point presentation available in the following link: https://www.rm.dk/globalassets/.../oplag.../6-oplag-willy-aastrup.pptx (03072019). 